\title{
Forecast Experiment of Long-Lived Subtropical Cumulonimbus Cluster with 6-Level y' km-Mesh Primitive Model
}

\author{
By K. Ninomiya and Y. Tatsumi \\ Electronic Computation Center, Japan Meteorological Agency, Tokyo 100, Japan
} (Manuscript received 21 November 1980, in revised form 1 July 1981)

\begin{abstract}
Forecast experiments on a medium-scale disturbance associated with a long-lived cumulonimbus cluster in the Asian subtropical humid region are made using a 6-level $77 \mathrm{~km}$-mesh primitive equation model. The purposes of the present study are to ascertain whether the medium-scale disturbance is predicted by using the present fine-mesh primitive model or not, and to inspect thermodynamic influence of cumulus convections on the development of the disturbance.

We make five experiments (Exp. 1 with standard moisture data, Exp. 2 with moist moisture bogus data as indicated by satellite IR cloud imagery, Exp. 3 with low-level moist moisture bogus data, Exp. 4 with artificial dry moisture bogus data and Exp. 5 without moist convective adjustment scheme) for each of the four development stages of the disturbance: formation, $\mathrm{Cb}$ cluster, $\mathrm{Cb}$ cluster-depression and depression stage. We also compare the results with prediction by 6L FLM (6-level $150 \mathrm{~km}$-mesh primitive model of JMA).

In the formation stage, the disturbance is located over the China Continent and the $\mathrm{Cb}$ cluster is apparently found on satellite IR cloud imagery. However, the amplitude of the disturbance is very weak, and the baroclinicity in the lower layers around the disturbance is very weak. For this period, all experiments can not simulate formation nor development of the disturbance.

For $\mathrm{Cb}$ cluster stage, Exp. 2 and 3 simulate the development of the disturbance while Exp. 1, 4, 5 and 6L FLM can not.

For $\mathrm{Cb}$ ciuster depression and depression stages, the predictions of all experiments are accurate to same extent. However, the precipitation in Exp. 4 and 6L FLM are much smaller.

The present study indicates the significant influence of cumulus convections on the development of the disturbance in $\mathrm{Cb}$ cluster stage. The accuracy of precipitation prediction in $\mathrm{Cb}$ cluster, $\mathrm{Cb}$ cluster depression and depression stage is evidently improved by the increase of the grid resolution and the improve of the initial analysis of the moisture field.
\end{abstract}

\section{Introduction}

The numerical prediction of intense convective rainfall, which tends to concentrate in a narrow zone, has been a problem for many years. Many authors (e.g., Hovermale (1975), Miyakoda and Rosati (1977), Anthes and Keyser (1979)) stressed in their studies of forecast experiment that improvement in the accuracy of rainfall prediction by primitive equation model is achieved through increased grid resolution.

It should be noted that the aforementioned experiments were made for the rainfalls associated with the polar frontal disturbances in the winter- spring season. More intense convective rainfalls occur frequently in the warm season in some southern parts of the middle latitude, where the baroclinicity of the atmosphere is not necessarily strong. For example, during the presummer rain season (June-July), Baiu front (a stationary front in the Asian subtropical humid region) lies along the Japan Islands, and weak frontal depressions bring strong convective rainfalls. Many observational studies (Matsumoto et al. (1970, 1971), Matsumoto and Ninomiya (1971), Ninomiya and Akiyama (1971), Akiyama (1973a, b, 1975, 1978, 1979), Yoshizumi (1977a, b), Ninomiya (1978, 1980), Ninomiya and Yamazaki (1979)) have 
shown that the features of Baiu front and associated disturbances are significantly different from those in polar frontal zone. (See Tokioka (1973) for the theoretical considerations.)

The operational 6-level $150 \mathrm{~km}$-mesh primitive equation model (6L FLM) used in JMA does not predict the development of medium-scale Baiu frontal disturbance accurately. The accuracy of precipitation prediction by $6 \mathrm{~L}$ FLM is significantly low in the Baiu-summer season. For example, the 6L FLM tends to predict concentrated precipitation in some unrealistic areas to the south of the surface disturbance (Nitta et al. (1979)).

Ninomiya and Tatsumi (1980) made real data forecast experiment for two typical cases of heavy rainfalls in Baiu front using a 6-level (in $\sigma$-coordinate) $77 \mathrm{~km}$-mesh regional primitive equation model. In order to get heavy rainfalls in more realistic position relative to actual frontal disturbance, they improved the moist convective adjustment scheme used in the 6L FLM by taking account of low-level vorticity and by modifying the critical lapse rate for the adjustment. The results of the experiments indicate that their model can predict the heavy rainfalls accurately to some extent. The experiments, however, did not include the case of heavy rainfall associated with a medium-scale disturbance, and therefore the performance of the model for a mediumscale disturbance has not been assessed yet.

Ninomiya, Ikawa and Akiyama (1981) made an observational study on a medium-scale disturbance associated with a long-lived $\mathrm{Cb}$ cluster, which migrated over the Asian subtropical humid region in 12-16 July 1979 . As the development process and the structure of this disturbance has been studied in detail, we take up this disturbance as an example for forecast experiment of a medium-scale disturbance.

\section{Observed features}

We will describe briefly the development process and features of the medium-scale disturbance studied by Ninomiya, Ikawa and Akiyama (1981).

(1) A long-lived $\mathrm{Cb}$ cluster accompanied by a medium-scale westerly trough migrates along $\sim 32^{\circ} \mathrm{N}$ latitude circle over the Asian subtropical humid region in 12-16 July 1979.

(2) GMS (Geostationary Meteorological Satellite) infrared radiation measurement shows that the cloud top temperature in the cluster is very low $\left(-60^{\circ} \sim-75^{\circ} \mathrm{C}\right)$ throughout the analysed period. This indicates that the cloud top reaches to tropopause.

(3) Surface, radar and raingage observations show that there are a number of mesoscale rainband $(\sim 150 \mathrm{~km}$ in length and $\sim 30 \mathrm{~km}$ in width) within the $\mathrm{Cb}$ cluster. Very strong rainfall $(50 \sim$ $100 \mathrm{~mm} /$ hour) concentrates in a certain part of the rainband. The areal and time averaged amount of rainfall over a domain of $(100 \mathrm{~km})^{2}$ is $\sim 20 \mathrm{~mm} /$ hour. The convective rainfalls are found under the high cloud shield of $\sim(200 \mathrm{~km})^{2}$ dimension.

(4) Over the China Continent, a frontal zone between monsoon airmass and continental tropical airmass extends along $\sim 32^{\circ} \mathrm{N}$ latitude circle. In this zone, the baroclinicity (or thermal gradient) is weak but the moisture gradient is large. The $\mathrm{Cb}$ cluster is formed in the frontal zone around $110^{\circ} \mathrm{E}$ in $12 \mathrm{July}$. During the passage of the $\mathrm{Cb}$ cluster along the frontal zone, the convections are very active but the surface pressure disturbance is not recognized under the $\mathrm{Cb}$ cluster ( $\mathrm{Cb}$ cluster stage; 12 14 July).

(5) When the $\mathrm{Cb}$ cluster moves into the baroclinic zone in the Pacific, a medium-scale frontal depression is formed (medium-scale depression stage; $15 \sim 16$ July).

(6) In the medium-scale depression stage, the vertical trough axis of the depression tilts northward with increasing height. Heavy rainfall area is found to the south of the upper (subtropical) jet stream axis and to the north of the low-level strong wind zone.

Temperature field at the $850 \mathrm{mb}$ level averaged for 12 GMT $12 \sim 12$ GMT 15 July is presented in Fig. 1. The locations of the $\mathrm{Cb}$ cluster at 12-

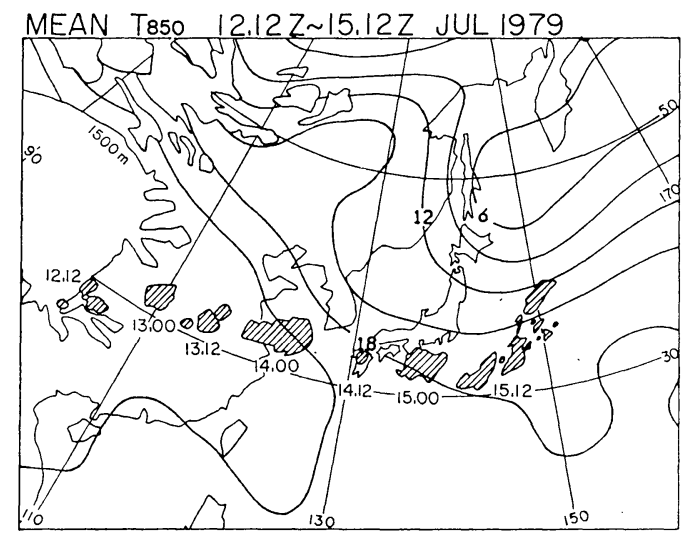

Fig. 1 Temperature field at $850 \mathrm{mb}$ averaged for 12 GMT 12 12 GMT 15 July 1979. The location of $\mathrm{Cb}$ cluster is shown at 12-hour interval. 
hour interval are shown in the figure. This map will elucidate the difference between the characteristics of the frontal zone over the continent and those over the Pacific.

\section{Description of model and experiment}

\subsection{Description of model}

The fine-mesh primitive equation model used in the present study is the same as that used by Ninomiya and Tatsumi (1980). Therefore we give only the following brief description;

Grid distance: $77 \mathrm{~km}$ at $30^{\circ} \mathrm{N}$ in polar stereographic projection.

Domain: Square area of $33 \times 33$ grid.

Vertical coordinate: 6 levels (uniform interval) in $\sigma$-system with the top at $100 \mathrm{mb}$.

Lateral boundary condition: Nested in one way in 4L NHM2 (4 level northern hemispherical model of JMA) through Davies (1976) boundary condition.

Physical process:

1) Sensible and latent heat exchange between the sea and the air.

2) Surface flux of momentum over the sea and the land.

3) Condensation and release of latent heat caused by grid-scale vertical motion ("large-scale condensation").

4) Thermodynamic process of subgrid-scale convective motions formulated with the dry convective adjustment scheme and that with the moist convective adjustment scheme revised by the present authors (Ninomiya and Tatsumi 1980).

5) Subgrid-scale horizontal diffusions of momentum, temperature and water vapor in Fickian type formulation $\left(e . g ., \nu \nabla^{2} T\right)$.

6) Vertical diffusions of momentum, temperature and water vapor in the lowest two layers.

7) Orographic effects with a smoothed topography.

8) Uniform cooling to counterbalance the total heating within the model.

\subsection{Selected period of prediction and develop- ment stage of disturbance}

One of the main purposes of the present study is to assess the prediction performance of the proposed model for the medium-scale disturbance. The prediction performance will depend on the development stage of the disturbance. Therefore we will make experiments for each of the four development stages listed in Table 1. Fig. 2 shows the area of the experiment for the four periods.

\subsection{Outline of experiments}

Another main purpose of the present study is to inspect the effect of cumulus convections. For the evaluation of the effect, we make five experiments, which are listed in Table 2, for the aforementioned four development stages.

Exp. $1 \sim 4$ include large-scale condensation, dry convective adjustment and moist convective adjustment revised by the present authors. Exp. $1 \sim 4$ are made to demonstrate the influence of initial moisture field on the development of the medium-scale disturbance and on the precipitation generated in the model. We know that

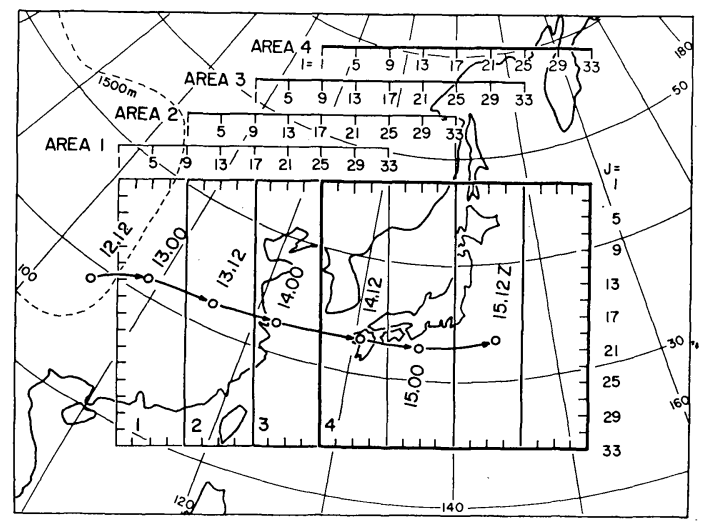

Fig. 2 domain of the prediction model for four stages of the $\mathrm{Cb}$ cluster listed in Table 1.

Table 1. Four development stage of the medium-scale disturbance for which the prediction experiments are made.

\begin{tabular}{lllll}
\hline Stage & Formation stage & Cb cluster stage & $\begin{array}{l}\text { Cb cluster } \\
\text { depression stage }\end{array}$ & Depression stage \\
\hline $\begin{array}{l}\text { Experiment } \\
\text { period }\end{array}$ & $\begin{array}{c}\text { 00GMT 13 } \\
\text { 00GMT 14 }\end{array}$ & $\begin{array}{c}\text { 12GMT 13 } \\
\text { 12GMT 14 }\end{array}$ & $\begin{array}{c}\text { 00GMT 14 } \\
\text { 00GMT 15 }\end{array}$ & $\begin{array}{r}\text { 12GMT 14 } \\
12 G M T ~ 15\end{array}$ \\
\hline Area & $\begin{array}{c}\text { Continent } \\
\text { (area 1) }\end{array}$ & $\begin{array}{c}\text { Continent } \\
\text { East China Sea } \\
\text { (area 2) }\end{array}$ & $\begin{array}{c}\text { East China Sea } ~ \\
\text { Pacific } \\
\text { (area 3) }\end{array}$ & $\begin{array}{c}\text { Pacific } \\
\text { (area 4) }\end{array}$ \\
\hline $\begin{array}{c}\text { Termal gradient } \\
\text { in frontal zone }\end{array}$ & Very weak & Weak & Weak & Strong \\
\hline
\end{tabular}


Table 2. Five experiments used for the present study.

\begin{tabular}{c|l|c}
\hline Exp. & $\begin{array}{l}\text { condensation and convective } \\
\text { process included in the model }\end{array}$ & initial moisture field \\
\hline Exp. 1 & $\begin{array}{l}\text { larg-scale condensation, dry } \\
\text { convective adjustment } \\
\text { and } \\
\text { moist convective adjustment } \\
\text { controled by low-level vorti- } \\
\text { city }\end{array}$ & $\begin{array}{c}\text { moisture field obtained by operational objective analysis } \\
\text { moist }(90 \%) \text { moisture bogus data* in the lowest } 3 \text { layers }\end{array}$ \\
\hline Exp. 2 & dry $(50 \%)$ moisture bogus data* in the lowest 3 layers \\
\hline Exp. 3 & $\begin{array}{l}\text { large-scale condensation and } \\
\text { dry convective adjustment }\end{array}$ & moist $(90 \%)$ moisture bogus data* in the lowest 3 layer \\
\hline Exp. 5
\end{tabular}

* Moisture bogus data are applied for $3 \times 4$ grid points by inspecting the GMS IR imagery.

observed moisture field shows usually small-scale pattern or localized variations while the conventional objective analysis scheme tends to smooth such small-scale moisture variations. In the forecast experiment of precipitation by a fine-mesh primitive equation model, Perkey (1976) pointed out that precipitation is significantly enhanced if the moisture bogus data are added by refering to the satellite cloud imagery.

The initial moisture field for Exp. 1 is obtained by the operational northern hemispherical objective analysis system of JMA. Exp. 1 is, therefore, a prediction experiment from smoothed initial moisture field.

In the actual atmosphere, high moisture content is usually localized within the convective disturbance. We add moist (relative humidity 90\%) moisture bogus data on $3 \times 4$ grid points within the $\mathrm{Cb}$ cluster found on GMS IR imagery for the initial moisture field of Exp. 2 and Exp. 3. For Exp. 2, bogus data are applied in the lowest 3 layers, and for Exp. 3 in the lowest 2 layers. Exp. 2 and Exp. 3 are the prediction experiments from more realistic initial moisture field.

Exp. 4 is the prediction experiment from an artificially dried initial moisture field. We add dry (relative humidity 50\%) moisture bogus data in the lowest 3 layers on $3 \times 4$ grid points within the $\mathrm{Cb}$ cluster for the initial moisture field of Exp. 4.

The comparison among the prediction by Exp. $1 \sim 4$ will demonstrate the influence of the moisture content and that of condensation upon the development of the medium-scale disturbance.

Exp. 5 does not include the moist convective adjustment scheme. The common initial moisture field is used for Exp. 2 and Exp. 5. The difference between the prediction of Exp. 2 and Exp. 5 will indicate the influence of the con- vective motions or the moist convective adjustment scheme upon the development of the medium-scale disturbance and precipitation.

We compare also the results of the aforementioned experiments with those obtained by 6L FLM.

\section{Results of experiments}

\subsection{Experiments for "depression stage"}

In this subsection we examine the 24-hour predictions of Exp. 1 5 for the "depression stage" of the medium-scale disturbance. The initial time of the experiment is 12 GMT 14 July 1979.

The initial $500 \mathrm{mb}$ and the surface maps are presented in Fig. 3.* The $\mathrm{Cb}$ cluster is located over Kyushu (western part of Japan). There are a weak $500 \mathrm{mb}$ trough over the southeastern coast of the Korea Peninsular and shallow surface lowpressure area around Kyushu (see $1004 \mathrm{mb}$ isobar). The initial $700 \mathrm{mb}$ mixing ratio field for Exp. 1 is presented in the bottom map in Fig. 3. As mentioned in section 3.3, we add moisture bogus data at $3 \times 4$ grid points within the $\mathrm{Cb}$ cluster for Exp. 2 5. Table 3 shows the initial mixing ratio within the $\mathrm{Cb}$ cluster of Exp. 1 5.

The differences among Exp. $1 \sim 5$ are most clearly seen in the distributions of vertical veloc-

Table 3. Mixing ratio within the $\mathrm{Cb}$ cluster at the initial time (12 GMT 14) of expeirments for "depression stage".

\begin{tabular}{lccc}
\hline & $900 \mathrm{mb}$ & $700 \mathrm{mb}$ & $500 \mathrm{mb}$ \\
\hline Exp. 1 & 17 & 10 & $4 \mathrm{~g} / \mathrm{kg}$ \\
Exp. 2 and 5 & 19 & 12 & 4 \\
Exp. 3 & 19 & 11 & 4 \\
Exp. 4 & 12 & 7 & 4 \\
\hline
\end{tabular}

* The initial and prediction maps presented in the present paper do not cover the whole domain of the prediction model. 


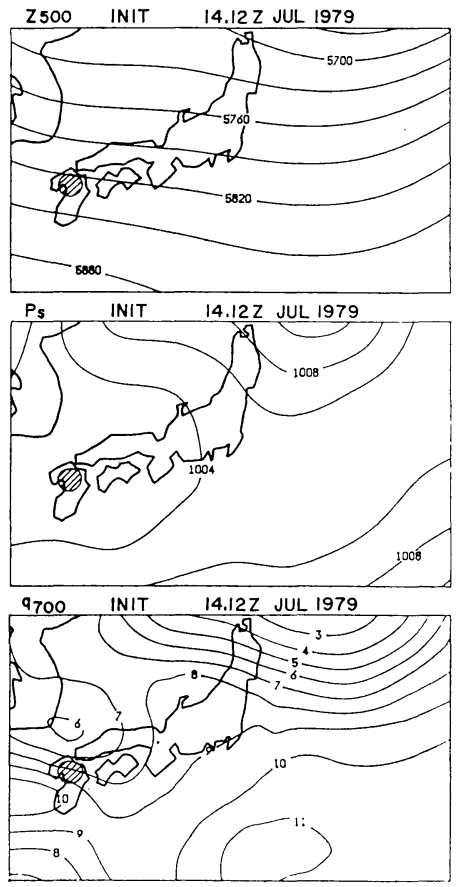

Fig. 3 Initial $500 \mathrm{mb}$ and surface map at 12 GMT 14 July 1979. The bottom map shows initial field of $700 \mathrm{mb}$ mixing ratio for Exp. 1.

ity and precipitation. Fig. 4 illustrates the locations of the "area of maximum 3-hour precipitation" predicted at every 3 hours in Exp. 1 5. The large and small numerals in Fig. 4 indicate the amount of maximum 3-hour rainfall and the time respectively. The location of $\mathrm{Cb}$ cluster observed by GMS IR imagery at 6-hour interval is presented on the top figure in Fig. 4.

Exp. 2 and 3 predict the movement of the intense rainfall area accurately. The predicted amount of the rainfall seems to be adequate, since the areal averaged observed precipitation is $10 \sim 20 \mathrm{~mm} / 3$ hour.

The area of maximum precipitation in $09 \sim 12$ GMT 15 predicted by Exp. 1 and 4 agree well with the observed location of the $\mathrm{Cb}$ cluster, though Exp. 1 and 4 do not produce the large amount of rainfall except the last 6-hour of the prediction period. It is inferred that the model takes $12 \sim 18$ hours to moisten the atmosphere in and around the disturbance, as Exp. 1 and 4 starts from the unmoistened and artificially dried initial moisture fields respectively.

Although the same initial moisture field is applied for Exp. 2 and 5, the precipitation

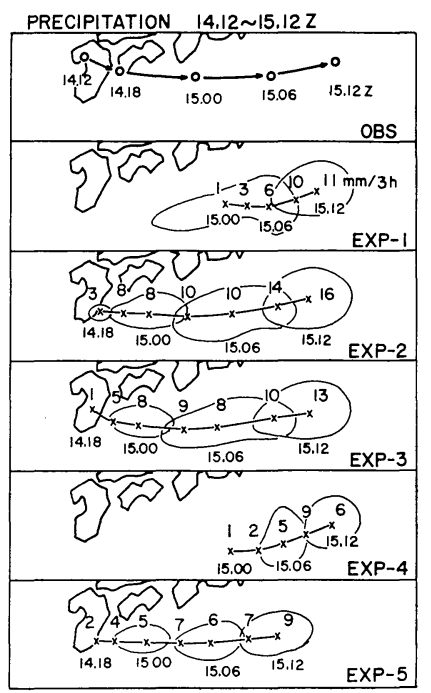

Fig. 4 Movement of heavy rainfall area predicted in Exp. 1 5 for "depression stage" (12 GMT $14 \sim 12$ GMT 15). The large numeral shows the maximum 3-hour precipitation and small numeral shows time respectively. The isohyet of $3 \mathrm{~mm} / 3$-hour is presented 6 hourly. The location of $\mathrm{Cb}$ cluster observed by GMS IR imagery is presented in the upper figure at 6-hour interval.

predicted in Exp. 5 is about half of that of Exp. 2.

\subsection{Experiments for " $\mathrm{Cb}$ cluster $\sim$ depression stage"}

We examine the 24-hour predictions of Exp. $1 \sim 5$ for " $\mathrm{Cb}$ cluster depression stage". The initial time is 00 GMT 14 July 1979.

The initial $500 \mathrm{mb}$ and the surface maps are presented in Fig. 5. The $\mathrm{Cb}$ cluster is located over the East China Sea. There are a very weak $500 \mathrm{mb}$ trough and a surface low-pressure area over the Yellow Sea. The initial $700 \mathrm{mb}$ mixing ratio field of Exp. 1 is presented in the bottom map in Fig. 5. Table 4 shows the initial mixing ratio within the $\mathrm{Cb}$ cluster of Exp. 1 5.

Fig. 6 illustrates the location of the "area of maximum 3-hour precipitation" predicted at every 3-hour by Exp. 1 5. Exp. 2tand Exp. 3 predict the movement of the intense rainfall area and amount of rainfall accurately in this stage too. The precipitation in Exp. 5'is' about 2/3 of that in Exp. 2. In Exp. 1, the area of : maximum precipitation for 21 GMT $14 \sim 00$ GMT 15 agrees with the observed location of $\mathrm{Cb}$ cluster, though the amounts of rainfall are much less than observed except the last 9 hours. Exp. 4, which 

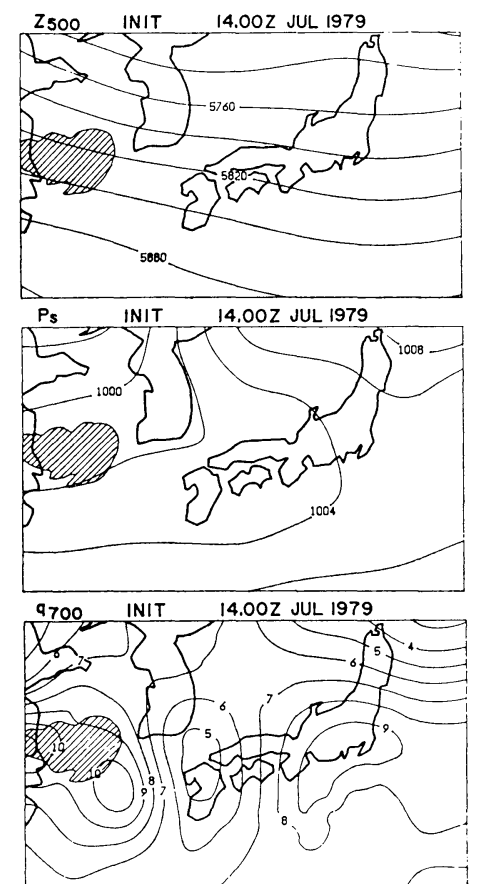

Fig. 5 Initial $500 \mathrm{mb}$ and surface map at 00 GMT 14 July 1979. The bottom map shows initial field of $700 \mathrm{mb}$ mixing ratio for Exp. 1.

Table 4. Mixing ratio within the $\mathrm{Cb}$ cluster at the initial time (00 GMT 14) of experiments for " $\mathrm{Cb}$ cluster depression stage".

\begin{tabular}{lccc}
\hline & $900 \mathrm{mb}$ & $700 \mathrm{mb}$ & $500 \mathrm{mb}$ \\
\hline Exp. 1 & 17 & 10 & $3 \mathrm{~g} / \mathrm{kg}$ \\
Exp. 2 and 5 & 20 & 12 & 3 \\
Exp. 3 & 20 & 10 & 3 \\
Exp. 4 & 12 & 7 & 3 \\
\hline
\end{tabular}

starts from the artificially dried initial moisture field, does not produce significant precipitation.

\subsection{Experiments for " $\mathrm{Cb}$ cluster stage"}

The initial time for the experiments for " $\mathrm{Cb}$ cluster stage" is 12 GMT 13 July 1979 . The initial $500 \mathrm{mb}$ map and the surface map are presented in Fig. 7. Although there is a very weak $500 \mathrm{mb}$ trough over the China continent, we can not find any surface disturbance in the vicinity of the $\mathrm{Cb}$ cluster. The initial $700 \mathrm{mb}$ mixing ratio field for Exp. 1 is presented in the bottom map in Fig. 7. Table 5 shows the initial mixing ratio within the $\mathrm{Cb}$ cluster for Exp. $1 \sim 5$.

As seen in Fig. 8, Exp. 2 and Exp. 3 predict the movement of the intense rainfall area and

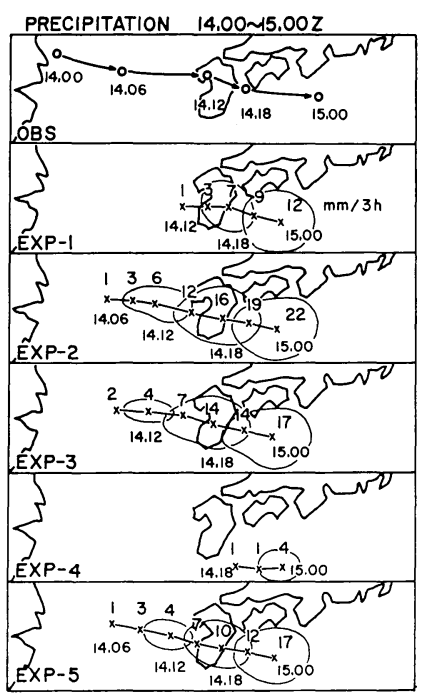

Fig. 6 Movement of heavy rainfall area predicted in Exp. 1 5 for " $\mathrm{Cb}$ cluster $\sim$ depression stage" (00 GMT 14 00 GMT 15 July). The large numeral shows maxi mum 3-hour precipitation and small numeral shows time.

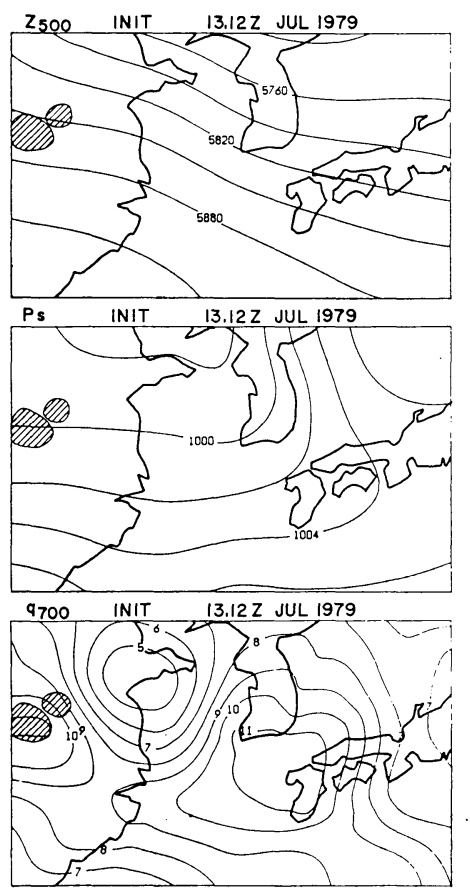

Fig. 7 Initial $500 \mathrm{mb}$ and surface map at 12 GMT 13 July 1979. The bottom map shows initial field of $700 \mathrm{mb}$ mixing ratio for Exp. 1. 
Table 5. Mixing ratio within the $\mathrm{Cb}$ cluster at the initial time (12 GMT 13) of experiments for " $\mathrm{Cb}$ cluster stage".

\begin{tabular}{lccc}
\hline & $900 \mathrm{mb}$ & $700 \mathrm{mb}$ & $500 \mathrm{mb}$ \\
\hline Exp. 1 & 19 & 11 & $4 \mathrm{~g} / \mathrm{kg}$ \\
Exp. 2 and 5 & 23 & 13 & 4 \\
Exp. 3 & 23 & 12 & 4 \\
Exp. 4 & 13 & 8 & 4 \\
\hline
\end{tabular}

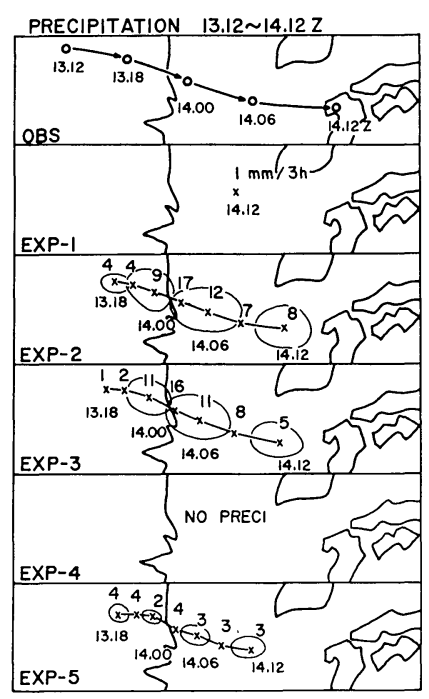

Fig. 8 Movement of heavy rainfall area predicted in Exp. 1 5 for "Cb cluster stage" (12 GMT 13 12 GMT 14 July). The large numeral shows maximum 3-hour precipitation and small numeral shows time.

the amount of rainfall properly in the " $\mathrm{Cb}$ cluster stage" too. The GMS IR observation shows the significant shrinking of the $\mathrm{Cb}$ cluster over the East China Sea (see Fig. 2 of Ninomiya, Ikawa and Akiyama 1981). It is interesting that the precipitation in the model reaches to peak value in 00 GMT 03 GMT 14 July and then decreases. We can not make sure, however, whether this decrease of predicted rainfall over the East China Sea corresponds to the observed decrease of the dimension of the $\mathrm{Cb}$ cluster.

Exp. 5 does not predict the precipitation nor the movement of precipitation area properly. Exp. 1 and Exp. 4 do not produce precipitation within 24 hours.

\subsection{Experiment for "formation stage"}

The initial time for the experiments for "formation stage" of the $\mathrm{Cb}$ cluster is $00 \mathrm{GMT}$ 13 July 1979 . The initial $500 \mathrm{mb}$ map and the surface map are presented in Fig. 9. At this time $\mathrm{Cb}$ cluster is over the surface high pressure area and the zonal flow predominates at $500 \mathrm{mb}$ in the vicinity of the $\mathrm{Cb}$ cluster. It was mentioned in section 2, that the baroclinicity (thermal gradient) is very weak in the "subtropical frontal zone" over the continent where the continental tropical airmass is adjacent to monsoon tropical airmass. The initial $700 \mathrm{mb}$ mixing ratio field for Exp. 1 is presented in the bottom map in Fig. 9. Table 6 shows the initial mixing ratio within the $\mathrm{Cb}$ cluster of Exp. 1 5.

In the "formation stage" of $\mathrm{Cb}$ cluster $(00$ GMT 13 00 GMT 14), Exp. 1 5 do not predict any precipitation nor the development of disturbance, though the migration of active $\mathrm{Cb}$ cluster along the subtropical frontal zone is seen

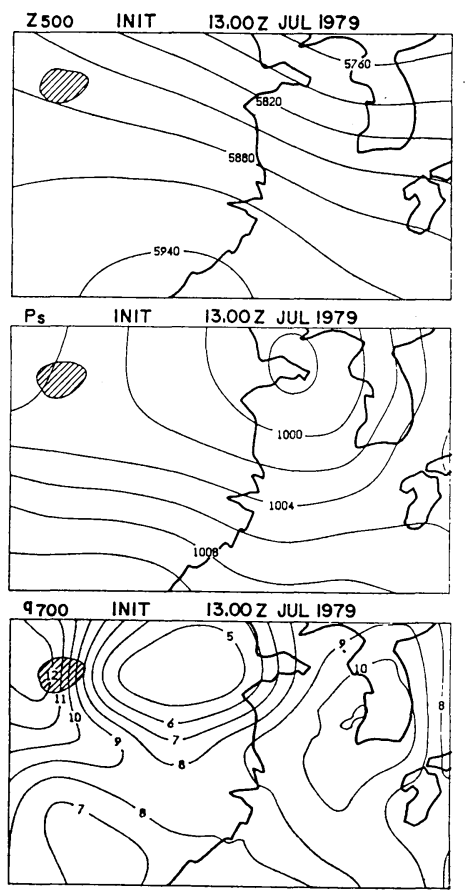

Fig. 9 Initial $500 \mathrm{mb}$ and surface map at 00 GMT 13 July 1979. The bottom map shows initial field of $700 \mathrm{mb}$ mixing ratio for Exp. 1.

Table 6. Mixing ratio within the $\mathrm{Cb}$ cluster at the initial time (00 GMT 13) of experiments for "formation stage".

\begin{tabular}{lccc}
\hline & $900 \mathrm{mb}$ & $700 \mathrm{mb}$ & $500 \mathrm{mb}$ \\
\hline Exp. 1 & 18 & 11 & $4 \mathrm{~g} / \mathrm{kg}$ \\
Exp. 2 and 5 & 21 & 13 & 5 \\
Exp. 3 & 21 & 12 & 4 \\
Exp. 4 & 12 & 8 & 4 \\
\hline
\end{tabular}




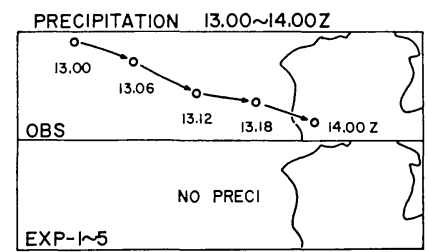

Fig. 10 Movement of $\mathrm{Cb}$ cluster observed by GMS IR imagery. Any precipitation is not predicted in Exp. 1 5 for "formation stage" (00 GMT 13 00 GMT 14 July).

on GMS IR imagery (Fig. 10). Predictions by Exp. 2 and Exp. 3 show merely elongated moist zone along the subtropical frontal zone. The present model is not able to predict the development of the medium-scale disturbance in the "formation stage".

4.5 Comparison with the predictions by $6 L$ FLM

In the present subsection, we compare the predictions by 6L FLM with those by Exp. 2 . Fig. 11 and Fig. 12 show precipitation predicted

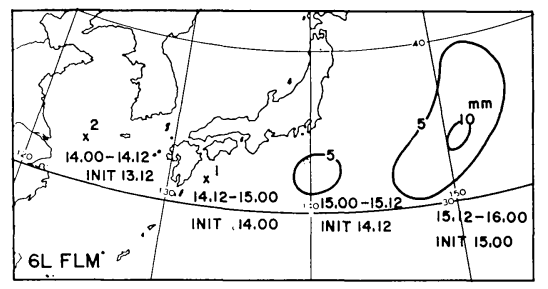

Fig. 11 Precipitation predicted by $6 \mathrm{~L}$ FLM for 00 GMT 14 12 GMT 14 (initial time 12 GMT 13), 12 GMT 14 00 GMT 15 (initial time $00 \mathrm{GMT} 14$ ), $00 \mathrm{GMT} \sim 12$ GMT 15 (initial time 12 GMT 14) and 12 GMT 15 00 GMT 16 (initial time 00 GMT 15).

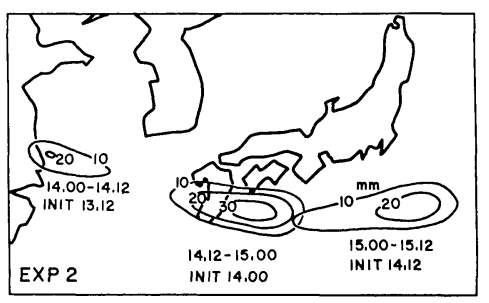

Fig. 12 Precipitation predicted by Exp. 2 for 00 GMT 14 12 GMT 14 (initial time 12 GMT 13), 12 GMT 14 00 GMT 15 (initial time $00 \mathrm{GMT} 14$ ) and $00 \mathrm{GMT}$ 15 12 GMT 15 (initial time $12 \mathrm{GMT}$ 14).

by $6 \mathrm{~L}$ FLM and Exp. 2.

It is seen that 6L FLM does not produce the precipitation for " $\mathrm{Cb}$ cluster stage" and " $\mathrm{Cb}$ cluster depression stage", while it predicts precipitation fairly accurately for and after the "depression stage". In short, the improvement in accuracy of rainfall prediction through increased grid resolution is especially evident for " $\mathrm{Cb}$ cluster stage" and " $\mathrm{Cb}$ cluster $\sim$ depression stage". The revised moist convective adjustment scheme used in Exp. 2 also contributes to concentrate the precipitation around the disturbance.

\subsection{Discussions}

Table 7 summarizes the results of rainfall predictions. The following remarks are made by inspecting the results of the experiments;

(1) The increase of grid resolution improve evidently the prediction accuracy of precipitation and the development of a medium-scale disturbance for " $\mathrm{Cb}$ cluster stage" and " $\mathrm{Cb}$ cluster depression stage", in which the amplitude and the horizontal extent of the disturbance are still

Table 7. Summarization of results of the precipitation prediction in the experiments.

\begin{tabular}{|c|c|c|c|c|}
\hline \multirow[b]{2}{*}{ Exp. } & \multicolumn{4}{|c|}{ Stage } \\
\hline & Formation stage & $\mathrm{Cb}$ cluster stage & $\begin{array}{l}\mathrm{Cb} \text { cluster } \\
\text { depression stag }\end{array}$ & Depression stage \\
\hline Exp. 1 & $\mathrm{D}$ & D & B & $\mathrm{C}$ \\
\hline Exp. 2 & D & A & A & A \\
\hline Exp. 3 & D & A & A & A \\
\hline Exp. 4 & $\mathrm{D}$ & $\mathrm{D}$ & $\mathrm{D}$ & $\mathrm{C}$ \\
\hline Exp. 5 & $\mathrm{D}$ & $\mathrm{D}$ & A & $\mathrm{C}$ \\
\hline 6L FLM & D & D & D & B \\
\hline
\end{tabular}

Note: A: Accurate in location and amount.

B: Accurate in location but small amount.

C: Some error in location.

D: Very small or no precipitation. 
small.

(2) The present $77 \mathrm{~km}$-mesh primitive equation model, which includes the revised moist convective adjustment scheme, is able to predict the precipitation and the development of the disturbance for and after the " $\mathrm{Cb}$ cluster stage".

(3) The present model is not able to produce precipitation for the "formation stage" of the $\mathrm{Cb}$ cluster.

(4) Addition of moist moisture bogus data into the area of $\mathrm{Cb}$ cluster results in the enhancement of precipitation in the model. This enhancement of precipitation is most evident in " $\mathrm{Cb}$ cluster stage" and "Cb cluster $\sim$ depression stage". The accurately analysed initial moisture field, which expresses the small-scale concentration of moisture, is important to improvement of the accuracy of precipitation prediction.

(5) When artificially dry moisture bogus data are added to the initial moisture field, the present model simulates neither the precipitation nor the development of the disturbance properly. Exp. 5 , the experiment do not include the moist convective adjustment scheme, do not predict precipitation accurately. These results indicate the influence of condensation and cumulus convections on the development of the medium-scale disturbance.

\section{Frontal zone and medium-scale disturbance predicted by the model}

In the present section, we examine the features of the frontal zone and the medium-scale disturbance predicted by Exp. 2.

\section{Medium-scale trough and depression}

The predicted $500 \mathrm{mb}$ height fields for $12 \mathrm{GMT}$ 14 (see Fig. 7 for the initial field at 12 GMT 13) and 12 GMT 15 (see Fig. 3 for the initial field at 12 GMT 14) are presented in Fig. 13. The hatched areas in Fig. 13 show the area of precipitation more than $3 \mathrm{~mm} / 3$ hour. The area of predicted strong precipitation is located $200 \sim$ $300 \mathrm{~km}$ east to the predicted weak trough. The location of the trough and the spatial relation between the trough and the area of active convections predicted in Exp. 2 agree well with these observed.

The predicted surface pressure fields for 00 GMT 15 (initial time 00 GMT 14) and 12 GMT 15 (initial time 12 GMT 14) are presented in Fig. 14. The dashed lines in Fig. 14 are the isolines of $900 \mathrm{mb}$ height anomaly $z_{900}^{\prime}$, which is defined as the deviation from "areal running

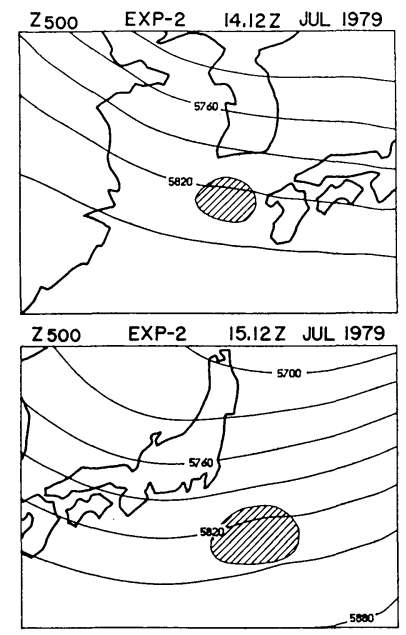

Fig. 13 Predicted $500 \mathrm{mb}$ height by Exp. 2 for 12 GMT 14 July (initial time 12 GMT 13) and 12 GMT 15 July (initial time 12 GMT 14). The hatched area shows the area of precipitation more than $3 \mathrm{~mm} /$ 3 hour.

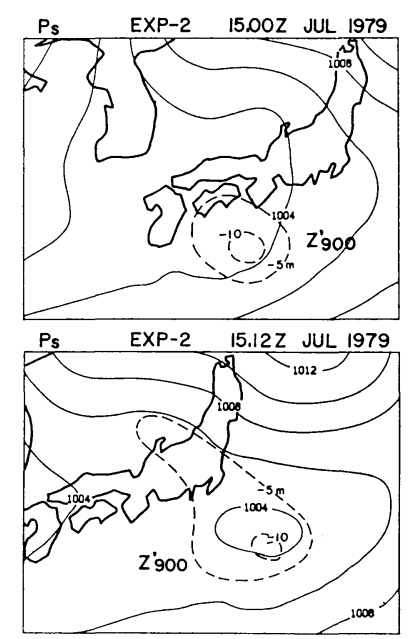

Fig. 14 Predicted surface pressure field by Exp. 2 for 00 GMT 15 (initial time 00 GMT 14) and 12 GMT 15 (initial time 12 GMT 14). The dashed lines are isoline of $900 \mathrm{mb}$ height anomaly from $11 \times 11$ grid areal running mean.

mean" over $11 \times 11$ grid area.

On the initial map at 00 GMT 14, neither closed isobar (see Fig. 5) nor medium-scale area of negative anomaly of $z_{900}^{\prime}$ is not found (figure is not presented) around the $\mathrm{Cb}$ cluster. On the predicted surface map for 00 GMT 15 , the closed isobar is not found yet. The predicted negative anomaly of $z_{900}^{\prime}$, however, clearly indi- 
cates the low level disturbance.

On the initial surface map at 12 GMT 14, wide and shallow low-pressure $(\sim 1004 \mathrm{mb})$ area is found over the western part of Japan (Fig. 3). Any medium-scale area of negative anomaly of $z^{\prime}{ }_{900}$ is not found at the initial time (figure is not presented). Both closed isobar $(1004 \mathrm{mb})$ and the medium-scale area of negative anomaly of $z_{900}^{\prime}(\sim-10 \mathrm{~m})$ are predicted nearby the observed $\mathrm{Cb}$ cluster for 12 GMT 15.

Exp. 2 predicts the formation of the mediumscale surface depression for the " $\mathrm{Cb}$ cluster depression stage".

\section{Front and stratification}

The meridional vertical cross sections along the grid line $I=19$ of $\theta, \theta_{e}, q$ and wind speed predicted by Exp. 2 for 00 GMT 15 are presented in Fig. 15A. The heavy rainfalls are predicted around the grid point $J=21$ on the abscissa of Fig. $15 \mathrm{~A}$.

The meridional gradient of $\theta$ around the heavy rainfall area is weak $(\sim 2 \mathrm{~K} / 300 \mathrm{~km})$ while the gradient of $\theta_{e}$ is strong $(\sim 10 \mathrm{~K} / 300 \mathrm{~km})$. Distribution of $q$ indicates that the heavy rainfall

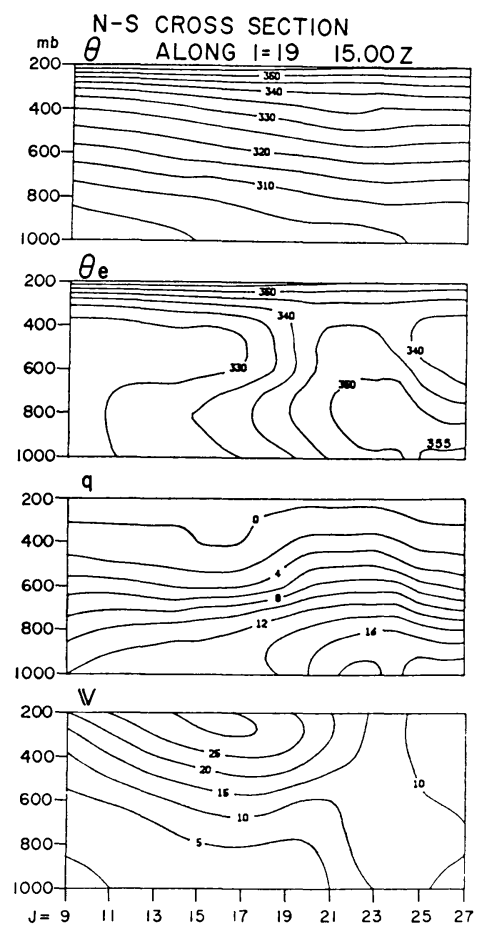

Fig. 15A Vertical cross section along $I=19$ of potential temperature $\theta$, equivalent potential temperature $\theta_{e}$, mixing ratio $q$ and wind velocity predicted by Exp. 2 for 00 GMT 15 (initial time 00 GMT 14).

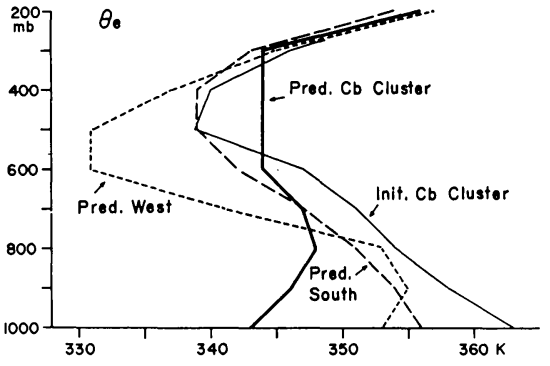

Fig. 15B Some examples of the vertical profile of initial (00 GMT 14) and predicted (00 GMT 15) equivalent potential temperature $\theta_{e}$.

takes place over the northern rim of the marine tropical airmass characterized by high moisture content $(\sim 16 \mathrm{~g} / \mathrm{kg})$.

The vertical profile of initial and predicted $\theta_{e}$ over a few grid points are presented in Fig. 15B. The profile of "Init. $\mathrm{Cb}$ cluster" (over $I=6, J=$ 19 at 00 GMT 14) is the $\theta_{e}$ profile within the $\mathrm{Cb}$ cluster at the initial time. The strong convective instability is owing to the very warm and moist airmass spreading over the southern part of China and the western part of the East China Sea (see Fig. 17 of Ninomiya, Ikawa and Akiyama 1981).

The profile of "Pred. $\mathrm{Cb}$ cluster" is the $\theta_{e}$ profile within the predicted heavy rainfall area (over $I=19, J=20$ at 00 GMT 15). The profile of "Pred. South" is $\theta_{e}$ profile predicted over the Pacific to the south of the frontal zone. The profile of "Pred. West" is the profile of $\theta_{e}$ predicted over the East China Sea, where the weak subsidence take place and the middle troposphere is dry.

The vertical cross section of $\theta_{e}$ in Fig. 15A and the $\theta_{e}$ profiles in Fig. 15B show that the convective instability tends to be released around the heavy rainfall area while the strong convective instability remains adequately in the marine tropical airmass over the Pacific to the south of the Japan Islands.

\section{Wind field}

Maps of predicted wind velocity at $300 \mathrm{mb}$ and $700 \mathrm{mb}$ by Exp. 2 are presented in Fig. 16. The bottom figure in Fig. 15A and Fig. 16 elucidate the predicted wind field around the "frontal zone". There are a high-level (200 $300 \mathrm{mb}$ ) wind maximum (high-level jet stream) along $\sim 37^{\circ} \mathrm{N}$ and a low-level $(700 \sim 800 \mathrm{mb})$ wind maximum along $\sim 31^{\circ} \mathrm{N}$. The heavy rain- 


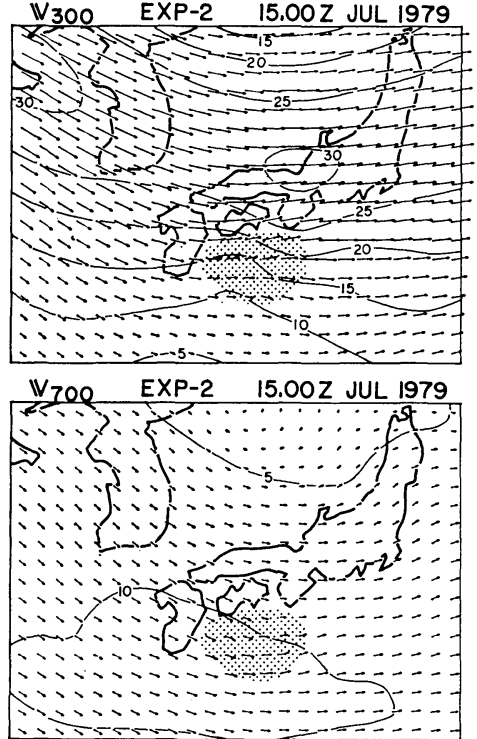

Fig. 16 Wind at $700 \mathrm{mb}$ and $300 \mathrm{mb}$ predicted by Exp. 2 for 00 GMT 15. The stippled area shows the area of predicted rainfall more than $3 \mathrm{~mm} / 3$ hour.
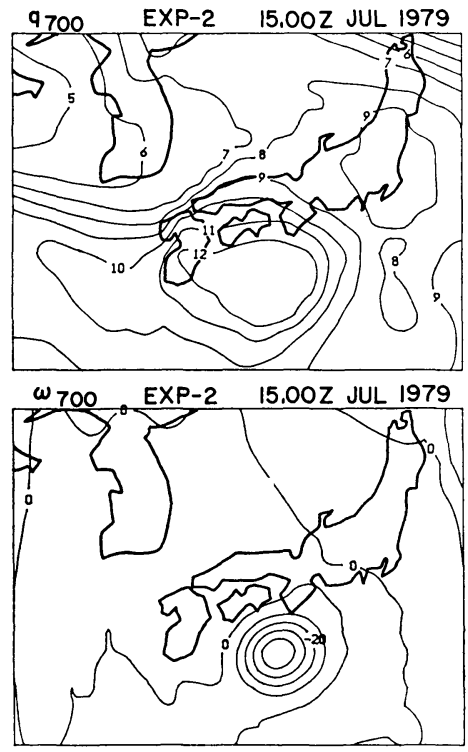

Fig. 17 Mixing ratio and vertical $p$-velocity at $700 \mathrm{mb}$ predicted by Exp. 2 for 00 GMT 15 July.

fall area and the frontal zone are located between the high-level wind maximum and the lowlevel wind maximum. The spatial relation between the front, high- and low-level wind maxima are predicted accurately.

\section{Vertical velocity and vorticity}

Predictions of $q_{700}$ (mixing ratio at $700 \mathrm{mb}$ ), $\omega_{700}$ (vertical $p$-velocity at $700 \mathrm{mb}$ ), $\zeta_{300}$ and $\zeta_{700}$ (vorticity at 300 and $700 \mathrm{mb}$ ) are presented in Fig. 17 and Fig. 18 respectively. At $700 \mathrm{mb}$, strong upward velocity $(\sim-40 \mathrm{mb} / \mathrm{hour})$ and high mixing ratio $(\sim 12 \mathrm{~g} / \mathrm{kg})$ are predicted over the surface depression.

In the lower troposphere $(1,000 \sim 600 \mathrm{mb})$, the cyclonic vorticity is found over the heavy rainfall area. The vorticity in $900 \sim 700 \mathrm{mb}$ layer is $\sim 60 \times 10^{-6} \mathrm{sec}^{-1}$. In the upper troposphere $(300 \sim 200 \mathrm{mb})$, strong anticyclonic vorticity appears over the low-level cyclonic vorticity.*

\section{"Diabatic heating"}

Next we inspect the horizontal and vertical distribution of "diabatic heating" $d \theta / d t$ in Fig. 19 and Fig. 20 predicted by Exp. 2. The "diabatic heating" $d \theta / d t$ is defined as the grid-scale diabatic heating in the model, i.e., $d \theta / d t$ is the change of $\theta$ due to the release of latent heat and the vertical convergence of convective and eddy (in the process of convective adjustment, diffusion and heat exchange between the sea and the air) heat transport in the model. Corresponding

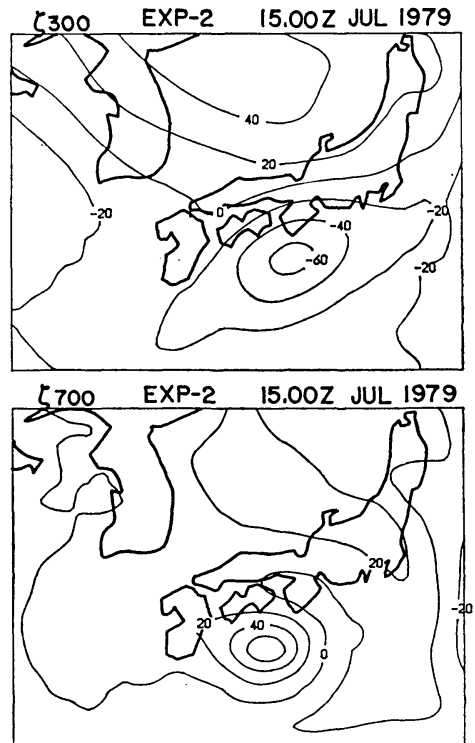

Fig. 18 Vorticity at $700 \mathrm{mb}$ and $300 \mathrm{mb}$ predicted by Exp. 2 for 00 GMT 15 July.

* The features of the vorticity field at the initial time (00 GMT 14) is described here: The low level cyclonic vorticity $\left(10 \sim 20 \times 10^{-6} \mathrm{sec}^{-1}\right.$ in $900 \sim$ $700 \mathrm{mb}$ layer) and the high level anticyclonic vorticity $\left(\sim-20 \times 10^{-6} \mathrm{sec}^{-1}\right.$ in $300 \sim 200 \mathrm{mb}$ layer $)$ are found around the $\mathrm{Cb}$ cluster. 


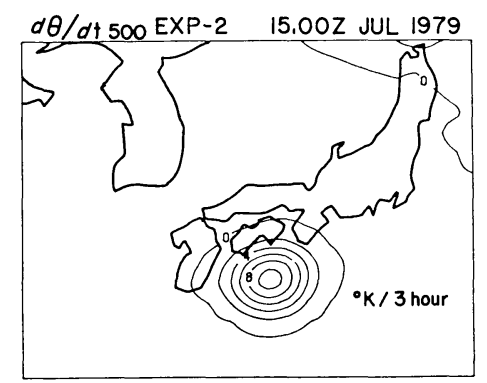

Fig. 19 The "diabatic heating" $d \theta / d t$ at $500 \mathrm{mb}$ predicted by Exp. 2 for $00 \mathrm{GMT}$ 15 July.

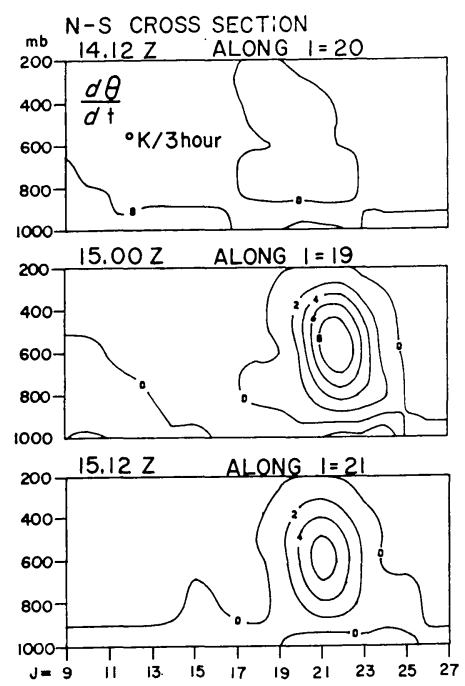

Fig. 20 Vertical cross section of "diabatic heating" $d \theta / d t$ predicted by Exp. 2 for 12 GMT 14 (initial time 12 GMT 13), 00 GMT 15 (initial time 00 GMT 14) and 12 GMT 15 July (initial time 12 GMT 14).

to the occurrence of the most intense precipitation ( $\sim 22 \mathrm{~mm} / 3$ hour), the largest diabatic heating $(\sim 9 \mathrm{~K} / 3$ hour) is computed for 00 GMT 15 (Fig. 20).

The vertical profile (maximum at $\sim 600 \mathrm{mb}$ ) and the magnitude $(\sim 3 \mathrm{~K} /$ hour $)$ of $d \theta / d t$ seems to be reasonable since the disturbance accompanies intence $\mathrm{Cb}$ cluster. Fig. 19 shows that the area of large diabatic heating predicted by Fig. 2 coincides with the $\mathrm{Cb}$ cluster observed.

Fig. 16 and Fig. 18 show that the strong upper anticyclonic vorticity with strong difluence and divergence is formed above the area of maximum $d \theta / d t$. This is a typical features of upper outflow over the intense convective storms (e.g.,
Fankhauser (1969), Ninomiya (1971, 1974), Ninomiya and Akiyama (1973) and MacDonald (1977)).

It is concluded that the features of front and the medium-scale disturbance predicted by Exp. 2 agree well with the features analysed by Ninomiya, Ikawa and Akiyama (1981).

\section{Summary}

Forecast experiments on development of a medium-scale disturbance in the Asian subtropical humid region associated with a long-lived $\mathrm{Cb}$ cluster are made using a 6-level (in $\sigma$-coordinate system) $77 \mathrm{~km}$-mesh primitive equation model. The purpose of the present study is to ascertain whether the present model predict accurately the medium-scale disturbance. We also inspect thermodynamic influence of cumulus convections on the development of the disturbance.

We make five experiments listed in Table 2 for four development stages of the disturbance listed in Table 1. The effect of the increased grid resolution upon the prediction accuracy is shown by comparing the predictions by the present model with those by the operational $150 \mathrm{~km}$-mesh model of JMA.

The improvement in prediction accuracy of precipitation and the development of the disturbance through increased grid resolution is most evident for " $\mathrm{Cb}$ cluster stage" and " $\mathrm{Cb}$ cluster depression stage", in which the disturbance is still weak. The present $77 \mathrm{~km}$-mesh model is able to simulate the precipitation, structure of the frontal zone and the structure of the disturbance and its development properly for the period in/ after the "Cb cluster stage", provided the moist moisture bogus data are applied by inspecting GMS IR imagery.

The present model is, however, not able to produce precipitation nor disturbance for the "formation stage" of $\mathrm{Cb}$ cluster even if the moist moisture bogus data are supplied. Further increase of horizontal and vertical resolutions of the model and the improvement of cumulus parameterization scheme will be needed to predict the formation of the medium-scale disturbance or $\mathrm{Cb}$ cluster.

Addition of moist moisture bogus data into the initial field in the area of $\mathrm{Cb}$ cluster results in the significant enhancement of precipitation. This enhancement is most evident in " $\mathrm{Cb}$ cluster stage" and " $\mathrm{Cb}$ cluster $\sim$ depression stage". The precipitation and development of the disturbance are not properly simulated by Exp. 4 (with artificially 
dry moisture bogus data) and Exp. 5 (not includes the moist convective adjustment scheme). The results indicate some important role of the condensation process and cumulus convections in the development of the medium-scale disturbance in " $\mathrm{Cb}$ cluster stage" and " $\mathrm{Cb}$ cluster $\sim$ depression stage".

\section{Acknowledgements}

The authors would like to express their hearty thanks to Mr. Y. Takigawa of Electronic Computation Center for providing the prediction values of $4 \mathrm{~L}$ NHM2 which are used for the boundary values of the present model.

\section{References}

Akiyama, T., 1973a: The large-scale aspects of the characteristic features of the Baiu front. Pap. Met. Geophy., 24, 157-188.

1973b: Frequent occurrence of heavy rainfall along the north side to the low-level jet stream in the Baiu season. Pap. Met. Geophy., 24, 379-388.

1975: Southerly transversal moisture flux into the extremely heavy rainfall zone in the Baiu season. J. Met. Soc. Japan, 53, 304-216.

1978: Mesoscale pulsation of convective rain in medium-scale disturbances developed in Baiu season. J. Met. Soc. Japan, 53, 276-273.

1979: Thermal stratification in Baiu frontal medium-scale disturbances with heavy rainfalls. J. Met. Soc. Japan, 57, 587-598.

Anthes, R. A., and D. Keyser, 1979: Tests of a finemesh model over Europe and the United States. M.W.R., 107, 963-984.

Davis, H.C., 1976: A lateral boundary formulation for multi-level prediction models. Quart. J. Roy. Met. Soc., 102, 405-418.

Frankhauser, J. C., 1969: Convective processes resolved by a mesoscale rawinsonde network. $J$. App. Met., 8, 778-798.

Hovermale, J., 1975: Accuracy of prediction of heavy precipitation events in relation to grid resolution in numerical models. Briefing of performance of NMC hurricane model at NOAA/ NMC Hurricane Center at Miami 1975.

MacDonald, A. E., 1977: On a type of strong divergent steady state. M.W.R., 105, 771-785.

Matsumoto, S., et al., 1970: On the structure of the Baiu front and the associated intermediatescale disturbances in the lower amtosphere. $J$. Met. Soc. Japan, 48, 479-491.

, et al., 1971: Characteristic features of Baiu front associated with heavy rainfall. J. Met. Soc. Japan, 49, 267-281.

—, and K. Ninomiya, 1971: On the meso- scale and medium-scale structure of a cold front and the relevant vertical circulation. J. Met. Soc. Japan, 49, 648-662.

Miyakoda, K. and A. Rosati, 1977: One-way nested grid models: The interface conditions and the numerical accuracy. M.W.R., 105, 1092-1107.

Nionmiya, K., 1971: Dynamical analysis of outflow from tornado-producing thunderstorms as revealed by ATS-III pictures. J. App. Met., 10, 275-294.

-1974: Mesoscale objective analysis of the wind and moisture field around the thunderstorms developed over NSSL observation network on May 28, 1967. Pap. Met. Geophy., 25, 81-97.

, 1978: Heavy rainfalls associated with frontal depression in Asian subtropical humid region (I). J. Met. Soc. Japan, 56, 253-266. 1980: Enhancement of Asian subtropical front from thermodynamic effect of cumulus convections. J. Met. Soc. Japan, 58, 1-15.

—_, and T. Akiyama, 1971: The development of the medium-scale disturbance in the Baiu front. J. Met. Soc. Japan, 49, 663-677.

, and $\longrightarrow$ 1973: Medium-scale echo clusters in the Baiu front as revealed by multiradar composite echo maps (II). J. Met. Soc. Japan, 51, 108-118.

- and Y. Tatumi, 1980: Front with heavy rainfalls in the Asian subtropical humid region in a 6-level $77 \mathrm{~km}$-mesh primitive equation model. J. Met. Soc. Japan, 58, 172-186.

, and K. Yamazaki, 1979: Heavy rainfalls associated with frontal depression in Asian subtropical humid region (II). J. Met. Soc. Japan, 57, 399-413.

- M. Ikawa and T. Akiyama, 1981: Development process and large-scale situations of long-lived medium-scale cumulonimbus cluster in Asian subtropical humid region. J. Met. Soc. Japan, 59, 564-577.

Nitta, Ta., Y. Yamagishi and Y. Okamura, 1979: Operational performance of a regional numerical weather prediction model. J. Met. Soc. Japan, 57, 399-413.

Parkey, D. J., 1976: A description and preliminary results from a fine-mesh model for forecasting quantitative precipitation. M.W R., 104, 15131526.

Tokioka, T., 1973: A stability study of mediumscale disturbances with inclusion of convective effects. J. Met. Soc. Japan, 51, 1-10.

Yoshizumi, S., 1977a: On the structure of intermediate-scale disturbances on the Baiu front. $J$. Met. Soc. Japan, 55, 107-120.

1977b: Preliminary report on the convective vertical transport of momentum over western Japan in the Baiu season. Pap. Met. Geophy., 28, 49-61. 


\title{
6 層 $77 \mathrm{~km}$ 格子プリミイテブモデルによる長続きした 亜熱帯 Cb クラスターの予報実験
}

\author{
二宮 洸 三・翼 保 夫 \\ 気象庁
}

6 層 $77 \mathrm{~km}$ 格子プリミイテブモデルを使用して 1979年 7 月 12１5 日に中国〜日本を通過した長続きした亜 熱帯 $\mathrm{Cb}$ クラスターをともなら中間規模擾乱の 24 時間予報実験を行ら。目的はこのモデルによる中間規模啰乱 とそれにともなら降雨の予報可能性をさぐり，かつ啰乱の発達におよぼす積雲対流の熱力学的効果を調べること である。

このため, 次の 5 種類の実験を行う：Exp. 1 4 は下層の渦度でコントロールされた湿潤対流調節を含み， Exp. 1 はルーチン客観解析システムによるスムーズされた水蒸気初期場から予報し, Exp. 2 は衛星画像を参照 して, Cb クラスター内の下部 3 層に湿った $(90 \%)$ 水蒸気ボーガスデーターを加光, Exp. 3 は下 2 層に加光, Exp. 4 は乾いた $(50 \%)$ 水蒸気ボーガスをクラスター内部の下 3 層に加える。Exp. 5 は湿潤対流調節を含まない (初期值は Exp. 2 に同じ)。現用 6 LFLM (150 hm 格子モデル) との比較も行う。

この実験を擾乱の “発生期”, “クラスター期”, “クラスター〜低気圧期”, “低気圧期”について行ら。

格子間隔の縮小によるシュミレーションの精度の向上は “クラスター期”〜“クラスター〜低気圧期”において 特に著しい。湿潤対流調節の有無, 小蒸気ボーガスの有無による差も“クラスター期”〜“クラスター〜低気圧 期” に著しく, この期間, 凝結・積雲の効果の大きなことが推論される。

一方, この実験モデルでは “発生期” の擾乱の発達や降水は, 水蒸気ボーガス・データーを加えてもシュミレ ートできなかった。“発生期” の状況をシュミレートするためには, さらに格子を縮小し, パラメタリゼーション や初期値解析を改良する必要がある。 